\title{
Değerlemenin ve Değerleme Ölçütlerinin Finansal Raporlama Kalitesindeki Belirleyici Rolü ${ }^{1}$
}

\section{Determining Role of Valuation and Valuation Criteria in Financial Reporting Quality}

\section{HATİCE ŞİMŞEK ${ }^{2 a}$}

\author{
a Sorumlu yazar/Responsible author
}

2 İstanbul Gelişim Üniversitesi, İstanbul Gelişim Meslek Yüksekokulu. hasimsek@gelisim.edu.tr Orcid ID: 0000-0003-0041-3406

$\begin{array}{ll}\text { Article Info: } & \text { Compilation } \\ \text { Date Submitted: } & 06.07 .2020 \\ \text { Date Revised: } & 01.03 .2021 \\ \text { Date Accepted: } & 11.03 .2021\end{array}$

\section{Abstract}

Financial reporting is the disclosure of financial results to management and external stakeholders about how the company has performed in a certain period of time. The quality of financial reporting determines the value of reporting. It is essential to provide high quality financial reporting to influence users and increase market efficiency when making investment decisions. The valuation is to determine the financial status and operating results of the company in a fair way. As the valuation process has a direct relationship between the structure of the balance sheet and the profit and loss situation, it is very important for accounting, which is the purpose of producing fair information. In the study, firstly, the subject of financial reporting and the quality of financial reporting were examined, what the criteria were, and then the importance of the valuation concept was emphasized in financial reporting and ensuring the quality of the report. Parallel to this, an evaluation was made with a SWOT analysis regarding the Financial Valuation Criteria. Thus, it is aimed to reveal the advantages, weaknesses, opportunities and threats of the valuation criteria.

Keywords: Financial Reporting, Reporting Quality, Valuation

JEL codes: M10, M41, D92

$\begin{array}{ll}\text { Makale Bilgisi: } & \text { Derleme } \\ \text { Geliş Tarihi: } & 06.07 .2020 \\ \text { DüzeltmeTarihi: } & 01.03 .2021 \\ \text { Kabul Tarihi: } & 11.03 .2021\end{array}$

Özet

Finansal raporlama, finansal sonuçların yönetim ve dış paydaşlara şirketin belirli sürede nasıl performans sergilediğ $i$ hakkında açıklanmasıdır. Finansal raporlamanın kalitesi raporlamanın değerini belirler. Yatırım kararları verirken kullanıcıları etkilemek ve piyasa verimliliğini artırmak için yüksek kaliteli finansal raporlama sağlamak esastır. Değerleme, şirketin mali durumu ve faaliyet sonucunu gerçeğe uygun biçimde belirlemektir. Değerleme işlemi bilançonun yapısı ve kâr - zarar durumu arasında da doğrudan ilişkisi olduğundan, gerçeğe uygun bilgi üretme amacı olan muhasebe açısından oldukça önemlidir. Çalışmada öncelikle finansal raporlama konusu ve finansal raporlama kalitesi konusu incelenmiş, ölçütlerin neler olduğu konusu irdelenmiş sonrasinda finansal raporlamada ve raporun kalitesinin să̆lanmasında değerleme kavramının önemi üzerinde durulmuştur. Buna paralel olarak Finansal Değerleme Ölçütlerine ilişkin SWOT analizi ile değerlendirme yapılmıştır. Böylelikle değerleme ölçütlerinin üstünlüklerinin ve zayıf yönlerinin, firsatlarının ve tehditlerinin ortaya konulması amaçlanmıştır.

Anahtar Kelimeler: Finansal Raporlama, Raporlama Kalitesi, Değgerleme

JEL kodları: M10, M41, D92

\footnotetext{
${ }^{1}$ Yazarlar bu çalışmanın tüm süreçlerinin araştırma ve yayın etiğine uygun olduğunu, etik kurallara ve bilimsel atıf gösterme ilkelerine uyduğunu beyan etmişlerdir. Aksi bir durumda Pamukkale Journal of Eurasian Socioeconomic Studies Dergisi sorumlu değildir. İntihal raporu alınmıştır.

The authors declared that all processes of this study comply with research and publication ethics and comply with ethical rules and scientific citation principles. Otherwise, Pamukkale Journal of Eurasian Socioeconomic Studies is not responsible. A plagiarism report is received.
} 


\section{EXTENDED SUMMARY}

Research Problem: It is aimed to emphasize the importance of the valuation used in financial reporting, the purpose and the importance of valuation criteria in ensuring the quality of financial reporting. For this purpose, in this study, firstly, the concepts of financial reporting and reporting quality are explained. Then, the importance of valuation, its purpose, and the criteria used in valuation were examined respectively. Finally, the effect of valuation criteria on financial reporting quality is examined.

Research Questions: What is the role of valuation and valuation metrics in financial reporting quality?

Literature Review: Financial reporting is the disclosure of financial results to management and external stakeholders about how the company performed over a period of time. The quality of financial reporting determines the value of reporting. Providing high quality financial reporting is essential to influence users and increase market efficiency when making investment decisions. Valuation is to determine the financial position and operating result of the company in a fair way. Since the valuation process has a direct relationship between the structure of the balance sheet and the profit and loss situation, it is very important in terms of accounting, which aims to produce truthful information.

Methodology: In the study, first of all, the subject of financial reporting and the quality of financial reporting were examined, the criteria were examined, and then the importance of the concept of valuation in financial reporting and in ensuring the quality of the report was emphasized. Parallel to this, an evaluation was made with a SWOT analysis of Financial Valuation Criteria. Thus, the strengths and weaknesses, opportunities and threats of valuation criteria are revealed.

Results and Conclusions: The scope of financial statements differs according to different valuation criteria used for assets and liabilities. For this reason, it is very important to determine the valuation criterion and to decide which items to use for which items. However, since the valuation scale used will differentiate the profit for the period, the selection of valuation criteria is very important. Thus, the valuation measure used affects both investors and the business as a whole. The reasons for the changes in the selection of the valuation criteria used in financial reporting may be due to the expansion and contraction of the activities of the institutions, the ability to change them as desired by cheating, make-up, technological and economic changes, the expansion of the capital market. Changes due to the factors listed cause the reporting to differ. Differentiated reporting affects the quality of the report. 


\section{GíRIŞ}

Şirketler faaliyetlerine devam edebilmek için yeterli kaynağa sahip olmak zorundadırlar. Yatırımcılardan kaynak sağlayabilmek amacıyla söz konusu yatırımcıların güveninin kazanılması gerekmektedir. Bir başka ifadeyle işletmeler şeffaflığın sağlanabilmesi amacıyla faaliyet sonuçlarını doğruluk ve dürüstlük ilkelerine uygun bir şekilde açılamak zorundadırlar. İşletmelerin bunları yaparken yararlandıkları en önemli araçlar finansal raporlama araçlarıdır. İlgili kişi veya tarafların açıklanan finansal raporlara güven duydukları takdirde, kaynaklara daha az maliyetle ulaşılacaktır. Finansal raporlama ile birlikte işletme hakkındaki doğru, kanıtlanabilir, tarafsız bilgilere ulaşılabilir. Finansal raporlamada yalnızca finansal tablolar yer almaz. Aynı zamanda yönetim kurulu faaliyet raporları, izah nameler, düzenleyici kuruluşlar tarafından hazırlanan raporlar, tahmin raporları gibi finansal tablolar dışındaki bilgiler de bulunmaktadır. Finansal raporlamanın çıktısı olan mali tablolar şirket paydaşlarının kuruluş hakkında veri sağlamada yararlandıkları temel araçlardan birisidir. Mali tabloları düzenleme amacına ulaşabilmesi amacıyla mali tablodan yararlananların gereksinim duydukları verileri vermesi gereklidir. İşletmelerin faaliyetlerini daha iyi değerlendirmek için raporlanan verilerin doğruluğunu içeren ölçüt ise finansal raporlama kalitesidir. Değerleme ölçütleri ise; işletmelerin varlıklarının bir başka ifadeyle faaliyet sonuçlarının gerçek değerini gösteren ölçütlerdir.

$\mathrm{Bu}$ çalışmada da finansal raporlama kalitesinin sağlanmasında finansal raporlamada kullanılan değerlemenin önemi, amacı, değerleme ölçütlerinin öneminin vurgulanması amaçlanmıştır. Bu amaçla, bu çalışmada öncelikle finansal raporlama ve raporlama kalitesi kavramları açıklanmıştır. Daha sonra, sırasıyla değerlemenin önemi, amacı, değerlemede kullanılan ölçütler incelenmiştir. Son olarak da, değerleme ölçütlerinin finansal raporlama kalitesine etkisi irdelenmiştir.

\section{FINANSAL RAPORLAMA KAVRAMI}

Finansal raporlar, raporlayan kuruluşun ekonomik kaynaklarında ve kuruluşa ilişkin haklarda farklılaşmaya sebep olan olayların etkileri hakkında bilgi verir. Kuruluşun mali kaynakları ile talep haklarının biçimi ve tutarlarına yönelik bilgileri raporlayan şirketin likiditesi ile borçları ödeme güçlerinin, ek finansman gereksiniminin ve bu finansmanların kazanımında hangi düzeyde başarılı olunacağının değerlendirilmesine yardım etmektedir (Doğan, 2014:89).

Finansal raporlamanın temel amacı, bir kuruluşun kâr ve kârın birleşenleriyle ölçülebilen finansal performansı konusunda bilgi sunmaktır. Finansal tablolar, finansal bilgi kullanıcılarının ekonomik kararlarında yararlı olacak biçimde, bir kuruluşun performansı, finansal durumu ve finansal durumlarındaki değişiklikler konusunda bilgi vermek için hazırlanmaktadır (Karabayır, 2012:21). Zira mali tabloların hazırlanma ve sun amac1, temelde finansal raporlamanın amacıyla örtüşmektedir (Demirkıran, 2010: 6).

Finansal raporlama süreci; finansal tabloların hazırlanması, bağımsız denetimden geçirilmesi ve kamuya açıklanması olarak üç asamaya ayrılır. Finansal raporlama sürecinin her bir aşamasında; işletme yönetimi, yönetim kurulu, muhasebe departmanı, iç kontrol sistemi ile tüm çalışanlarının rolü bulunmaktadır. Finansal raporlama sürecinde rol alan her departman ve çalışanın mali tabloların doğruları yansıtıp yansıtmamasıyla alakalı sorumlulukları bulunur (Arı, 2007:10). 


\subsection{Finansal Raporlamanın Kalitesi}

Finansal raporlama kalitesi, finansal tabloların güvenilirlik, anlaşılabilirlik, ihtiyaca uygunluk ve karşılaştırılabilirlik gibi faktörleri yerine getirebilme seviyesini ifade etmektedir. Bir başka tanıma göre, finansal raporlama kalitesi, mali tablolardaki verilerin gerçeğe uygunluğunu ya da yatırımcılara işletme faaliyetleriyle ilgili sunulmuş olan verinin hassaslığını ve doğruluğunu ifade etmektedir. Tüm bilgi sistemlerindeki gibi, muhasebe bilgi sisteminin amacı, ilgili kişilere veya kuruluşlara karar verme sürecinde yardım edecek ve tatmin edecek kaliteli verilerin sağlanmasıdır. Zira muhasebe verileri, ilgili kişi ve kurumların karar vermedeki durumunu direkt olarak etkiler. Bundan dolayı da neredeyse tüm dünya ülkelerinde muhasebe verilerinin kalitesinin arttırılabilmesi için finansal raporlama standartları oluşturulmakta ve uygulanmaktadır (Cengiz. vd. 2017:425). Ülkeler arasında muhasebe kalitesi ve ekonomik etkinlik yönünden çok fazla farklılıklar bulunduğundan, uluslararası muhasebe sistemleri finansal raporlamanın ekonomik çıktılarını araştırmada büyük firsatlar sunmaktadır (Soderstrom \& Sun, 2007). Kaliteli finansal raporlamanın kuruluşlara sağladığı yararlar bilinse de, bilginin elde edilmesi ve sunulmasına ilişkin maliyetler sebebiyle günümüzde maalesef şeffaflık tam anlamıyla sağlanamamaktadır.

\subsection{Finansal Raporlama Kalitesi Ölçütleri}

Finansal raporlamadaki kalite kuruluşlar için çok önemli bir değere sahiptir. Eğer finansal raporlamanın kalitesi yüksek ise kuruluşların sermaye maliyeti düşük seviyede olacaktır. Bununla birlikte kuruluşların finansal raporlarını kaliteli yapmaları, gerek finansal piyasaların etkinliğini sağlayarak finansal krizin riskini azaltacak gerekse kuruluşların mali durumunun daha kolay tespit edilmesini sağlayıp tasarrufların yatırımlara yönelmesini, böylelikle de sermaye maliyetlerinin azalmasına olanak sağlayacaktır. Ayrıca yüksek finansal raporlama kalitesi, şirketlerin fon kaynaklarını belirleyebilme üstünlüğünü yükseltir. Aksi durumda yani kalitesi düşük olan finansal raporlama, şirketlerin bankalardan yüksek maliyetli fon sağlamasına yol açar. Zira ilgili kişi veya kurumlar doğruyu yansıtmayan verilerle yanlış karar alabilme düşüncesi ile kuruluşa fon vermeye fazla istekli olmamaktadır. Bankalar da gereksinim duydukları bilgileri dolaysız şekilde söz konusu kuruluştan temin edebilir ve finansal raporlama kalitesi düşük olan işletmelerle yaptıkları borç sözleşmelerinde daha yaptırımı yüksek faiz ve vade koşulları uygulayabilmektedir (Cengiz. Vd. 2017:425).

Finansal raporlama kalitesine ilişkin araştırmacılar farklı türde ölçütler önermişlerdir Francis vd. (2006) ise kazanç kalitesine ilişkin 7 ölçüt önermiştir. Söz konusu ölçütler piyasa-temelli ve muhasebe-temelli ölçütler olmak üzere ikiye ayrılmıştır. Muhasebe temelli ölçütler "tahakkuk kalitesi", "tahmin edilebilirlik" "süreğenlik" ve "değişkenlik" tir ve muhasebe raporlarından elde edilen verilere dayanmaktadırlar. Piyasa-temelli ölçütler ise "zamanında sunum" , "değere ilişkinlik" ve "ihtiyatlılık "tır. Bu ölçütler gerek muhasebe raporlarından gerekse piyasada elde edilen verilere dayanmaktadırlar. Finansal raporlama kalitesinin ölçümünde kullanılan bu ölçütler sunulmuş olan bilgilerin kullanım amaçlarına bağlı olarak bunların doğru ve güvenilir olduğunun tespit edilmesini sağlar. Sunulan bilgi kalitesi ile sağlamış olduğu yararın orantılı olduğu düşünüldüğü takdirde, raporlamanın kalitesi için bilgilerin doğru ve eksiksiz şekilde sunulması gereklidir. Dolayısıyla, finansal raporlamanı kalitesi için işletmenin yöneticisi ve dış paydaşlar arasındaki gerçekleşen asimetrik bilgiyi 
azaltmaktadır. Bilgi asimetrisinin azalmasıyla da daha şeffaf raporlama yapılmış oluyor (Durak ve Gürel, 2014:96).

Finansal raporlama kalitesinde kullanılan ölçütler şu şekildedir;

Tahakkuk Kalitesi: Tahakkuklar, kazançların üretilmesinde muhasebe sürecinin en önemli çıktılarından birisidir. Zira işletme yöneticileri kendi yargılarını kullanıp fırsatçı bir yaklaşımla tahakkukları yönetebilir. Böyle bir durumda kazançların, işletmenin performansını yansıtmada daha az güvenilir ve daha az kaliteli olmasına sebep olabilir (Karabayır, 2012:65).

Süreğenlik (Süreklilik): Kazancın sürekli olması her zaman istenilen bir faktördür. Böyle bir durumda, açıklanmış olan kazancın ileriki zamanlarda da devam edeceği ve gelecek hakkında da veriler sağlayabileceği düşünüldüğü zaman süreğenliğin artması ile kazanç kalitesinin de yükseleceği bir gerçektir (Durak ve Gürel, 2014:97).

Tahmin Edilebilirlik: Bu ölçüt geçmişte raporlanmış olan kazanç performansının gelecekte gerçekleşmesi beklenen kazancın öngörülmesinde de kullanılabilir olmasını ifade etmektedir. Tahmin edilebilirlik raporlama kalitesiyle orantılı olduğu gerçektir. Dolayısıyla bu durum standart koyucular ve analistler tarafindan istenen bir durumdur (Karabayır, 2012:65).

Düzlük: Finansal tablolarda bulunan bilgilerin seçimi ve sunumu yönünden, ilgili kişilerin karar vermelerini etkileyip, önceden belirlenen, istenen sonuçlara ulaşmalarını gerçekleştirmek amacıyla hazırlanırlarsa bu türdeki finansal tablolarda buluna veriler taraflı olacaklarından dolayı güvenilirliği sağlamamış olurlar. Zira mali tablolarda yer alan verilerin hiçbir kişi ya da tarafın çıkarlarını koruma amacıyla değil tarafsız şekilde oluşturulması gerekmektedir (Demirkıran, 2010:19). İşletme yöneticilerinin gelecekte gerçekleşecek kazançlara yönelik özel nitelik taşıyan bilgileri de dönemin kazancıyla uyumlaştırılması amacıyla yararlanması sebebiyle bu raporların bilgilendirme niteliğinin yükseldiği böylece de kaliteli finansal raporlamaya etki ettiği düşüncesi yaygındır. Böyle bir durum bu özelliğinin istenilen bir durum olduğuna dikkat çeker (Demski, 1998: 275).

Değere İlişkinlik: Bu özellik, kazanç tutarının hisse senetleri fiyatlarındaki etkisini belirleme yeteneği olarak tanımlanmaktadır. Bundan dolayı bu özelliğin artıyor olması istenilir (Barth vd., 2001: 481)

Sunumun zamanında olması: Bu özellik, kamuya açıklanan verilerin muhasebe karındaki etkileme hızını açıklamaktadır (Ball vd., 2000:7). Bu özellik bilginin vazgeçilmez niteliklerinden biridir. Bazı bilgiler eskidikçe yararı azalsa bile, raporlama dönemi bittikten sonra da kullanışlı olmaya devam edebilir (Eskin, 2013:52).

İhtiyatlılık: Bu özellik, daha yüksek şeffaflık ve daha güvenilir kazançların göstergesi şeklinde kabul edilmektedir (Karabayır, 2012:65). İhtiyatlılık kamuya açık bilgilerin mali tablolara aktarılma zamanlılığı ile ilgilidir. Bununla birlikte olumsuz verilerin mali tablolara aktarılmasında muhtemel duruma erişmesinin yeterli olmasına rağmen, olumlu verilerin aktarılabilmesi için kesinleşmesinin beklenilmesi gerekliliğini açıklamaktadır (Ball vd., 2000:8). 


\subsection{Finansal Raporlama Kalitesinin Karakteristikleri}

Finansal bilgilerin ilgili kişilere yarar sağlayabilmesi için temel olarak dört özelliğe sahip olması gerekmektedir (KGK, Kavramsal Çerçeve; 2018);

İhtiyaca Uygunluk: Sunulmuş olan bilgi geçmiş, hâlihazırdaki ve öngörülen performans hakkında bilgi verebildiği ölçüde yararlı ve ihtiyaca uygun olur. Böylelikle işletme ilgili kişilere gereksinimlerine uygun veriler sağlayıp beklentileriyle risklerini karşılaştırıp teyit ve düzeltme imkânı sunmaktadır (TFRS, 2009: 11). Bilginin tahmin değeriyle yatırımcılar, kreditörler ve diğer ilgililer geçmişe dair sunulmuş bilgiler yardımı ile gelecek hakkındaki beklentilerini gerçekleştirebilmektedirler. Geçmişe dair sunulmuş olan verilerin hiçbiri geleceğe yönelik bir kesinlik ifade etmez. Ancak geçmişe dair söz konusu bilgiler olmadan geleceğe yönelik planlar ve değerlemeler yapılamaz. Bilginin teyit değeri ise geçmiş döneme yönelik değerlemeler üstünden geçmişteki beklentilerin gerçekleşme seviyesi belirlenip doğrulama yapılır (Karasioğlu, 2001:46). Herhangi bir mali tablo kalemine ilişkin bilginin ihtiyaca uygun bilgi olması için söz konusu bilginin tahmin etme ve düzeltme özelliklerine sahip olması gerekmektedir. Fakat böyle bir bilgi, karar vericilerin yatırım kararlarında farklılıklar oluşturabilir (Ulusan, 2007:533).

Anlaşılabilirlik: ilgililere sunulan verilerin faydalı olmasında anlaşılabilir olması gerekir. Mali tabloların, iktisadi faaliyetler ya da işletme ile ilgili sunulmuş bilginin ilgili kişileri tatmin edecek bir düzeyde olması gerekmektedir. Bununla birlikte sunulmuş olan veri ile verilmek istenilen verinin anlaşılır olabilmesi amacıyla gereken özenin gösterilmesi gerekir. Bilginin sınıflandırılması, karakterize edilmiş olması, açık ve kısa olarak sunulması onun anlaşılabilir olduğunu gösterir. Sunulan bilgiler kullanıcılar tarafından anlaşılır ancak bu durum kararlarını etkilememektedir. Çünkü bazı durumlarda bilgiler anlaşılmadığı için sunulan bilginin yararı olmamaktadır (Karasioğlu, 2010:145).

Güvenilirlik: Güvenilir kazançlar, firmanın performansını daha iyi yansıtacağı ve kullanıcılara daha yararlı bilgiler vereceği için, daha kaliteli olarak kabul edilirler (Karabayır, 2012:65). Güvenilirlik, mali tabloların doğru bilgi veren ve bu sebeple mali tablo kullanıcılarının güvenebildiği ve dış denetimce doğrulanabilen yansız değerlemelere sahip olmasını gerektirir (Ulusan,2007:534).

Karşılaştırılabilir Olma: Karşılaştırılabilirlik, kullanıcıların bilgiler arasındaki benzerlik ve farklılıkları tespit edebilmesini sağlar. Söz konusu ilke, finansal bilgiden yararlananların belli zamanda işletmenin mali durumu ve faaliyet sonuçlarındaki değişiklikleri tutarlı yöntemler izlenerek geçmiş yıllar itibariyle bununla birlikte benzer işletmelerin mali tabloları ile karşılaştırma olanağına sahip olmasını ifade eder (Karasioğlu, 2010:149).

\section{DEĞERLEME KAVRAMI}

Türk Dil Kurumu, değer kavramını, "satın alınmak istenen mal ya da hizmetin alıcılar veya satıcılar nezdinde oluşturulan kıymet ile ilişkili iktisadi bir kavramı ifade eder." Şeklinde tanımlamıştır (TDK, 2020). Yani bu tanıma göre değer, belli zaman içinde mal veya hizmetler için ödenmesi olası bir fiyatın takdirini ifade eder Değerleme ise, "işletmenin faaliyetlerine, aktif ve pasiflere parasal bir kıymet tayin edilmesi işlemidir. Değer, statik bir kavram olmasına rağmen, değerleme ise belirli bir süreci kapsadığı için dinamik bir süreci ifade eder. Aynı zamanda değerleme, değerin belirlenmesinde uygulanacak hesaplamaları, değerleri ve değer 
ölçütlerinin tespit edilmesi ve bu ölçütlerin uygulanarak mali tablolara aktarılması sürecini kapsar (Eskin, 2013:97).

Değerlemede amaç, kuruluşun mali durumunu ve faaliyetlerinin sonuçlarını gerçeğe uygun şekilde açıklayabilmektir. Değerleme işlemi bilançonun yapısı ve kâr ve zarar durumu arasında da direkt ilişkisi olduğu için, gerçeğe uygun bilgi üretme hedefi olan muhasebe için oldukça önemlidir. Bilanço unsurlarının tek tek ele alınıp değerlemeye tabi tutulması ve farklı bilanço kalemleri için farklı değerleme ölçütlerinin kullanılabilir olması, aynı zamanda kimi bilanço kalemleri için farklı zamanlarda farklı değerleme ölçütlerinin kullanılması, değerleme sürecini oldukça karmaşık biçime getirmektedir. İktisadi kıymetlerin miktar şeklinde belirlenmesinde hiç bir sorun yaşanmazken, bu kıymetleri tutar şeklinde dönüştürürken miktarların hangi değerlerle çarpılacağı farklılık gösteriyor olması da değerlemeyle ilgili bir diğer sorunlardan biridir (Eskin, 2013:99).

\subsection{Finansal Raporlamada Değerleme Ölçütleri}

Finansal Raporlamaya ilişkin Kavramsal Çerçeve Hakkında Tebliğ̆e de finansal tabloların değerleme esasları açıklanmıştır. Tebliğde, finansal tablolarda değişik derecelerde ve değişik bileşimlerde kullanılan değerleme esasları aşağıda belirtilmiştir (KGK, Kavramsal Çerçeve; 2018);

Tarihi Maliyet: "Varlıklar, elde edildikleri tarihte alımlarında ödenen nakit ya da nakit benzerlerinin tutarları ile ya da onları karşılayacak varlıklar gerçeğe uygun değerleriyle ölçümlenirler. Borçlar borcun karşılığında kazanılan tutarıyla ya da şirketin normal faaliyetlerinden kaynaklı borçlarda, borcun geri kapatılması için gerekli nakit ya da nakit benzerlerin tutarıla gösterilir."

Cari Maliyet: “Varlıklar aynı varlığın ya da söz konusu varlık ile eşdeğerdeki varlığın alınmasında mevcut gereken nakit veya benzerlerinin değerleriyle gösterilirler. Borçlar ise, yükümlülüğün kapatılmasında gereken nakit ya da nakit benzerlerinin sskonto edilmemiş tutarlarıla gösterilir."

Gerçekleşebilir Değer: “Varlıklar, şirketin normal faaliyetlerinde, bir varlığın elden çıkarılması durumunda elde edilecek olan nakit ya da benzerlerinin tutarıdır. Borçlar ise, şirketin mevcut faaliyet koşullarında, kapatılmalarında ödenmesi gerekli nakit ya da nakit benzeri değerlerin iskonto edilmemiş tutarlarıyla gösterilir."

Bugünkü Değer: "Varlıklar, kuruluşun mevcut faaliyet koşullarında, gelecek zamanda yaratacakları net nakit girişlerinin bugünkü iskonto edilen değerleri ile gösterilirler. Borçlar ise şirketin normal faaliyet koşullarında, kapatılmalarında ileride ödenmesi gerekli net nakit çıkışlarının bugünkü iskonto edilmiş değerleriyle gösterilir."

Finansal raporlamada genel olarak tarihi maliyet kullanılırken varlıklar ve borçları değerlerken karma değerleme yöntemlerinden de yararlanabilir.

\section{FINANSAL DEĞERLEME ÖLÇÜTLERINE İLIŞKİN SWOT ANALIZİ}

Finansal Değerleme Ölçütlerinin üstünlükleri, zayıf yönleri, fırsatları ve tehditlerine ilişkin Swot analizi Tablo 1'de gösterilmiştir. 
Tablo 1: Finansal Değerleme Ölçütlerine İlişkin SWOT Matrisi

\begin{tabular}{|c|c|}
\hline ÜSTÜNLÜKLER & ZAYIF YÖNLER \\
\hline 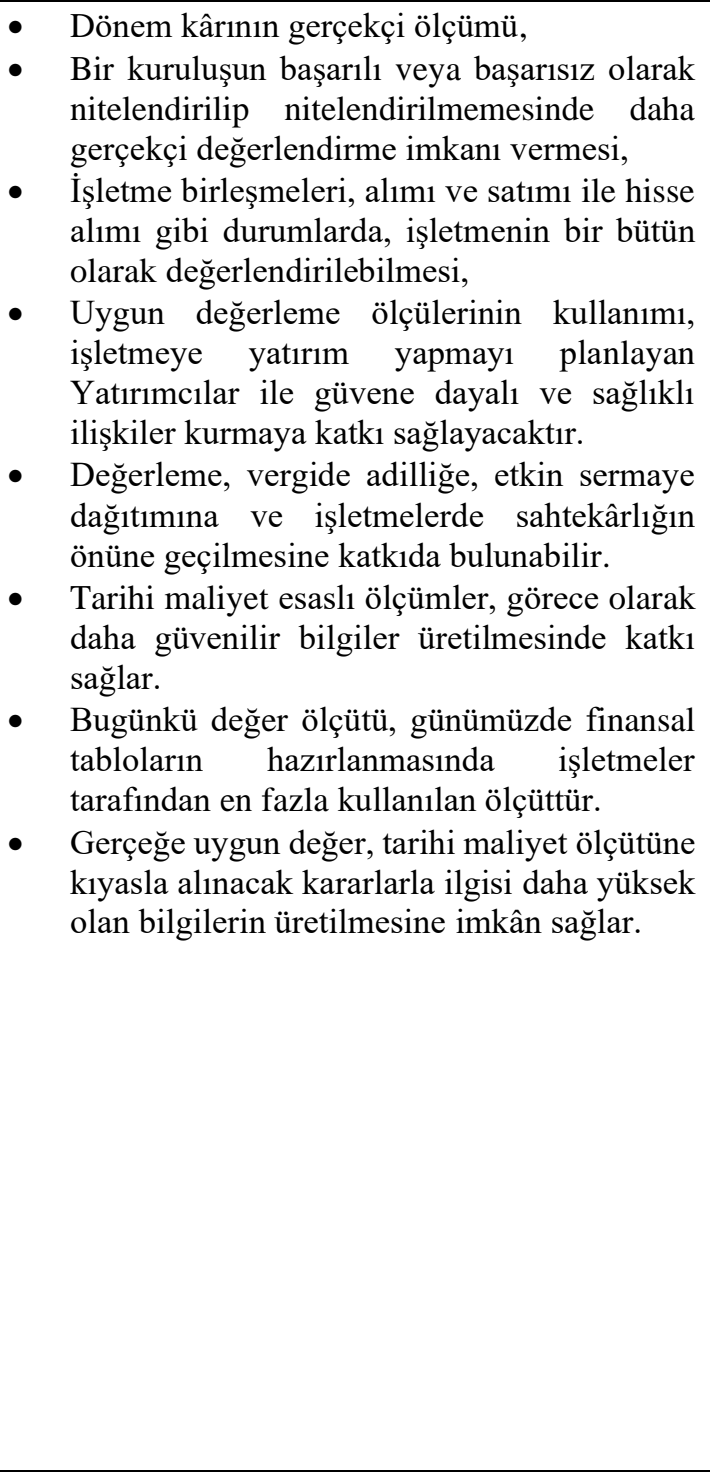 & 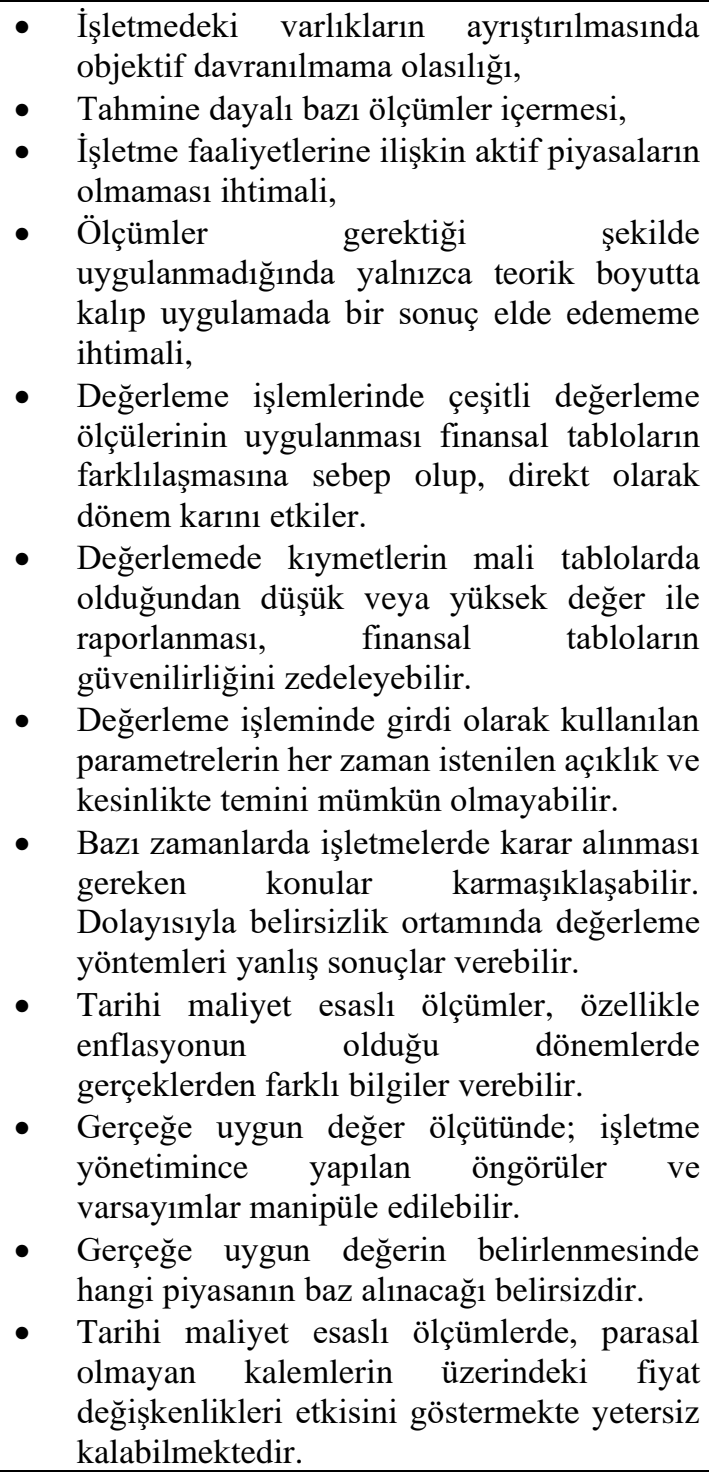 \\
\hline FIRSATLAR & TEHDİTLER \\
\hline $\begin{array}{l}\text { - İşletmelere yönelik leasing, swap, forward } \\
\text { gibi yeni iş yapma biçimlerinin ortaya } \\
\text { çıkması. } \\
\text { - Küresel sermaye piyasalarının artması, } \\
\text { - Git gide artan bilgi gereksinimi, } \\
\text { - Kamuyu aydınlatmaya yönelik önemin } \\
\text { artması } \\
\text { - Finansal bilgi kullanıcılarının } \\
\text { gereksinimlerinin farklılaşması, } \\
\text { - İnternet ve iletişimde yaşanan gelişmeler, } \\
\text { - Finansal raporlamaya yönelik değerleme } \\
\text { işlemleri; ülkeler, sektörler ve işletmeler } \\
\text { arasında sermaye dağıtımının belirlenmesine } \\
\text { yardımcı olur. }\end{array}$ & 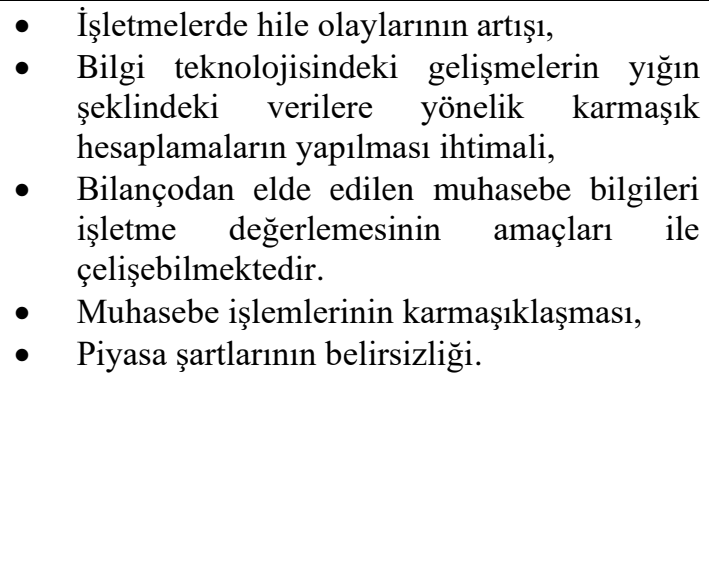 \\
\hline
\end{tabular}


Finansal bilgi kullanıcıları açısından finansal tablolardaki bilgilerin gerçeğe uygunluğu ve güvenilirliği son derece önem arz etmektedir. Finansal tablolardaki söz konusu bilgilerin gerçeğe uygunluğu ise; değerlemede yararlanılan ölçütlere bağlıdır. SWOT analizinde gerek finansal değerleme ölçütlerinin genel değerlendirmesi hem de değerleme ölçütleri arsındaki üstünlükler ve zayıf yönler değerlendirilmiştir.

\section{SONUC}

Finansal bilginin ve raporlamanın kalitesinde, raporlamada kullanılan değerleme ölçütü oldukça önemli rol oynar. Zira gerçeği yansıtmayan ölçütler finansal bilginin kalitesini düşürür. Dolayısıyla seçilen değerleme yöntemi gerek raporlamada gerekse sermayenin ve gelirin ölçülmesinde son derece önemli rol oynamaktadır.

Günümüzde değerleme yalnızca mali tablolarda bulunan varlık ve borçlarının gerçek değerlerini ifade etmek ya da dönem kârının doğru ölçülmesini sağlamak amacı ile yapılmamaktadır. İşletmenin bütünüyle değerine bakılmaya ve doğru değerleme yapılmasına gereksinim vardır Kimi zaman bazı kalemler için değerlemede zorunlu olarak tahminde bulunulması gerekir. Ancak bu durum kullanılan değerleme ölçütlerini bazı kalemler için sübjektif hale getirir. Bu da şirketin şeffaflığını, raporlamanın güvenilirliğini ve kalitesini etkiler. Bununla birlikte Finansal raporlamada sadece finansal tablolar da bulunmamaktadir. Aynı zamanda; yönetim kurulu faaliyet raporları, işletmeye yönelik tahmin raporları gibi raporlar da bulunur. Tüm bunların güvenilir olduğu aşamada finansal raporlama kalitesi yükselecektir.

$\mathrm{Bu}$ çalışmada finansal raporlama ve finansal raporlama kalitesi konusu incelenmiş, değerleme ölçütlerinin neler olduğu konusu incelenmiş sonrasında ise finansal değerleme ölçütlerine ilişkin SWOT analizi ile değerlendirme yapılmıştır. Böylece finansal değerleme ölçütlerinin üstünlükleri, zayıf yönleri, fırsatları ve tehditleri ortaya konulmuştur. Mali tabloların kapsamı varlık ve borçlar için kullanılan farklı değerleme ölçütlerine göre farklılaşmaktadır. Bu sebeple değerleme ölçütünün belirlenmesi ve hangi kalemler için hangisinin kullanılacağı kararı oldukça önem arz eder. Bununla birlikte kullanılan değerleme ölçeği dönem karını farklılaştıracağı için değerleme ölçütü seçimi çok önemlidir. Böylelikle, kullanılan değerleme ölçütü gerek yatırımcıları gerekse işletmenin bütününü etkiler. Finansal raporlamada kullanılan söz konusu değerleme ölçütleri seçimindeki değişiklikleri sebebi kuruluşların faaliyetlerini genişletip daraltması, hile, makyajlama yapılarak istenilen şekilde değiştirilebilmesi, teknolojik ve ekonomik değişiklikler, sermaye piyasasının genişlemesinden ileri gelebilir. Sayılan etkenler nedeniyle oluşan değişiklikler raporlamanın farklılaşmasına sebep olur. Farklılaşan raporlama, raporun kalitesini etkiler.

Mali tablolar bir işletmenin sürekliliğinin göstergesi niteliğindedir. Zira mali tablolar işletmenin anlık durumunu ve faaliyet sonuçlarını, para akışını, öz sermayesinin durumunu gösterir. Böylelikle mali tablo kullanıcıları ise tüm bu durumları değerlendirip söz konusu işletme hakkında karar alırlar. Bu sebepten ötürü mali tablolar gerçeği yansıtmalıdırlar. Aksi halde üzerinde değişiklikler yapılan mali tablolar, ekonomik krizlere dahi yön verebilir. Küreselleşmeden dolayı yatırım kararlarında mali tablo verilerinin daha fazla sorgulanmasına sebep olmuştur. Verilerin doğruluğu, güvenilirliği ve anlaşılabilirliğinin olmaması işletme açısından birçok kötü senaryoya yol açabilir. Yatırımcılar finansal raporlara olan güvenleri kazanıldığında, işletmeler düşük maliyetli ve istenilen tutarda kaynak elde edebilecektir. 


\section{Araştırmacıların Çatışma Beyanı / Researchers'Conflict of Interest Statement}

Yazarlar, bu çalışmada potansiyel bir çıkar çatışması olmadığını beyan etmişlerdir.

The authors declare that there is no potential conflict of interest in this study.

\section{KAYNAKÇA}

Arı, M. (2007). Finansal Raporlamaya Olan Güvenin Arttırılmasına Yönelik Yeni Yaklaşımlar, Marmara Üniversitesi, Sosyal Bilimler Enstitüsü, Yayınlanmamış Doktora Tezi, İstanbul.

Ball, R.- Kothari, S.P.- Robin, A. (2000) “The Effect Of International Institutional Factors On Properties Of Accounting Earnings". Journal Of Accounting And Economics, 29, 1-51.

Barth, M.- Beaver, W.- Landsman, W. (2001) "The Relevance Of The Value Relevance Literatüre For Financial Accounting Standard Setting: Another View". Journal Of Accounting And Economics, 31, 77-104.

Cengiz, S., Dinç, Y. ve Tosunoğlu, B. (2017). Finansal Raporlama Kalitesi İle Yatırım Verimliliği Arasındaki İlişkinin İncelenmesi: Borsa İstanbul'da (Bist) Bir Uygulama, International Journal Of Eurasia Social Sciences, 8 (28). 421-439.

Demirkıran, H. (2010). Finansal Raporlamanın Güvenilirliğinin Sağlanmasında Bağımsız Denetimin Rolü: Bir Uygulama. Dokuz Eylül Üniversitesi, Sosyal Bilimler Enstitüsü, Yayınlanmamış Doktora Tezi, İzmir.

Demski, J. (1998) “Performance Measure Manipulation”. Contemporary Accounting Research, $15,261-285$.

Doğan, S. (2014). Vuk Hükümlerine Göre Oluşturulan Mali Tabloların Tfrs Hükümlerine Uyarlanması Ve Analizi, Kahramanmaraş Sütçü İmam Üniversitesi, Sosyal Bilimler Enstitüsü, Yayınlanmamış Yüksek Lisans Tezi, Kahramanmaraş.

Durak, G., \& Gürel, E. (2014). Finansal Raporların Kalitesine Etki Eden Ülkeye Özgü Faktörler. Muhasebe Ve Finansman Dergisi, (64), 95-110.

Eskin, İ. (2013). KOBİlerin Gerçeğe Uygun Değer İle Finansal Raporlanması ve Bir Turizm İşletmesinde Uygulama. Trakya Üniversitesi, Sosyal Bilimler Enstitüsü, Yayınlanmamış Doktora Tezi, Edirne.

Francis, J.- Olsson, P.- Schipper, K. (2006). “Earnings Quality" Foundations And Trends İn Accounting, 1(4), $259-340$.

Kamu Gözetimi Kurumu (2018). Finansal Raporlamaya İlişkin Kavramsal Çerçeve. Ankara: Resmi Gazete (30578 sayılı)

Karabayır, M. E. (2012). Uluslararası Finansal Raporlama Standartları Ve Muhasebe Kalitesi: İMKB Örneği. Ankara Üniversitesi, Sosyal Bilimler Enstitüsü, Yayınlanmamış Doktora Tezi. Ankara.

Karasioğlu, F. (2001). İnternet Tabanlı Finansal Raporlama. Nobel Yayın Dağıtım, Ankara.

Soderstrom, N. S., \& Sun, K. J. (2007). Ifrs Adoption And Accounting Quality: A Review. European Accounting Review, 16(4), 675-702. 
Tfrs, 2009. “Tfrs 1 Türkiye Finansal Raporlama Standartlarının İlk Uygulamasına İlişkin Türkiye Finansal Raporlama Standardı". (Sayı: 27217 Resmi Gazete).

Türk Dil Kurumu (TDK), https://sozluk.gov.tr/. Erişim Tarihi:06.05.2020.

Ulusan, H. 2007. Finansal Raporlama Açısından Değerleme. Çukurova Üniversitesi Sosyal Bilimler Enstitüsü Dergisi. 16 (2), 525-543. 